\title{
Evaluation of the relation between the horizontal condylar angle and the internal derangement of the TMJ - a magnetic resonance imaging study
}

\section{Avaliação da relação entre o ângulo horizontal do côndilo e o desarranjo interno da ATM, por meio de ressonância magnética}

Iêda Margarida Rocha Crusoé-Rebello*

Paulo Sérgio Flores Campos**

Izabel Regina Fischer Rubira**

Jurandyr Panella***

Carlos Maurício Cardeal Mendes****

\begin{abstract}
This research aimed at assessing the relation between the horizontal condylar angle (HCA) and the internal derangement (ID) of the temporomandibular joint (TMJ), as a result of interference by the TMJ disk, in individuals undergoing magnetic resonance (MR) scans. The sample included a total of 144 TMJs (sagittal and coronal views) of 72 subjects, 15 of whom were male and 57 female, with ages ranging from 15 to 70 . The scans were made in a Signa system (GE) model at a magnetic field magnitude of $1.5 \mathrm{~T}$. Sixty-eight TMJs were found to be normal, while 46 showed anterior displacement with reduction. Of these, 41 had some kind of adaptive change in the condyle, while 5 showed degenerative changes. Anterior displacement without reduction was found in 29 joints, 12 of which showed adaptative changes in the condyle, while 17 showed degenerative changes. Only one posterior displacement of the articular disk was recorded. For the TMJs in which disk displacement was found, such values achieved $24.69^{\circ}$ on the right side, and $22.94^{\circ}$ on the left side. Hence, it was possible for us to conclude that the HCA tends to increase in those TMJs where ID is present. For contralateral TMJs, a strong association was observed between HCA values (57.8\%), state of normality $(69.7 \%)$, and ID (66.7\%). To corroborate such findings, a correlation between contralateral HCA values (63.31\%) and the diagnosis for contralateral TMJs $(68.05 \%)$ was determined. Thus, we could infer that there is a tendency between contralateral TMJs to share characteristics and conditions.
\end{abstract}

DESCRIPTORS: Temporomandibular joint; Nuclear magnetic resonance; Temporomandibular joint disk.

\begin{abstract}
RESUMO: Esta pesquisa teve por objetivo avaliar a relação entre o valor do ângulo horizontal do côndilo (AHC) e o desarranjo interno (DI), por interferência do disco da articulação temporomandibular (ATM), de indivíduos indicados para exame por ressonância magnética (RM). A amostra perfez um total de 144 ATMs (cortes sagital e coronal) de 72 indivíduos, na faixa etária de 15 a 70 anos, 15 do gênero masculino e 57 do gênero feminino. Os exames foram procedidos em um sistema modelo Signa (GE), magnitude de 1,5 T para o campo magnético. Sessenta e oito ATMs apresentaram uma condição de normalidade e 46 apresentaram deslocamento anterior do disco articular com redução. Dessas, 41 expressaram algum tipo de alteração adaptativa no côndilo e cinco, alterações degenerativas. Vinte e nove articulações mostraram deslocamento anterior do disco articular sem redução, sendo que 12 dessas apresentaram alterações adaptativas do côndilo e 17, alterações degenerativas. Foi registrado apenas um caso de deslocamento posterior do disco articular. O valor médio encontrado para o AHC do lado direito foi de $22,09^{\circ}$ e para o lado esquerdo foi de $21,47^{\circ}$, para aquelas ATMs que se apresentaram em condições de normalidade. Para as ATMs com deslocamento de disco, esses valores foram de $24,69^{\circ}$ para o lado direito e $22,94^{\circ}$ para o lado esquerdo. Desse modo, foi-nos possivel concluir que existe uma tendência ao aumento do AHC nas ATMs com DI. Observamos forte associação, para as ATMs contralaterais, entre os valores do AHC $(57,8 \%)$, condição de normalidade $(69,7 \%)$ e DI $(66,7 \%)$. E, corroborando esses resultados, registramos correlação para os valores dos AHC contralaterais $(63,31 \%)$ e o diagnóstico para as ATMs contralaterais $(68,05 \%)$. Assim, pudemos inferir que existe tendência das ATMs contralaterais apresentarem as mesmas características e condições.
\end{abstract}

DESCRITORES: Articulação temporomandibular; Ressonância magnética nuclear; Disco da articulação temporomandibular.

* PhD, Professor, FAPESB Researcher (Fundação de Amparo à Pesquisa do Estado da Bahia - Research Support Foundation of the State of Bahia).

** PhD, Professor, Department of Propaedeutics and Integrated Clinic, School of Dentistry; ****PhD, Professor, Collective Health Institute, School of Medicine - Federal University of Bahia.

*** Chairman, Department of Radiology, School of Dentistry, University of São Paulo. 
Crusoé-Rebello IMR, Campos PSF, Rubira IRF, Panella J, Mendes CMC. Evaluation of the relation between the horizontal condylar angle and the internal derangement of the TMJ - a magnetic resonance imaging study. Pesqui Odontol Bras 2003;17(2):176-82.

\section{INTRODUCTION}

The expression Temporomandibular Dysfunction (TMD) has been used in a generic way to diagnose facial pain and dysfunction of the jaws $\left(\right.$ Sano $^{15}$, 2000). Although referred to as a syndrome, nowadays researches support the hypothesis that TMD is a group of disorders related to the masticatory system, including intra-articular morphologic abnormalities, myalgias, different types of disk displacement, articular degenerative diseases, inflammatory arthritis, synovitis, and congenital and neoplastic conditions that affect the Temporomandibular Joint (TMJ). Since disk displacement is the most frequent among these disorders, the use of a more specific term could undoubtedly enhance clinicians' and researchers' understanding of the problem. To this end, the term Internal Derangement (ID) has been applied to refer to a disk's abnormal relationship with the articular bone components. This disorder is often characterized by an anterior articular disk displacement, with or without reduction (Paesani et al. ${ }^{12}$, 1992; Dolwick et al. ${ }^{3}, 1983$; Tallents et al. $\left.{ }^{16}, 1996\right)$.

Concerning the relationship between the disk and the articular bone components, Magnetic Resonance (MR) and arthrography are the imaging scans that have the greatest ability of providing the most necessary and optimized information for the establishment of accurate diagnoses (Heffez et al. ${ }^{5}$, 1995). As a method, however, MR has the advantages of being non-invasive, not using ionizing radiation and causing less discomfort for patients (Katzberg ${ }^{8}$, 1989).

In medical orthopedics, the spatial relationship between the articular bone components has been a discovery of great clinical importance. Alterations in the alignment of the knee joint components, for instance, are associated with local alterations in flexibility and articular compression, and osteoarthritis is a probable consequence (Pullinger et al. $\left.{ }^{13}, 1986\right)$.
Studies in dentistry have suggested that the Horizontal Condylar Angle (HCA), established between its long axis (medial-lateral) and the coronal plan, is higher in joints affected with ID than in normal joints, with approximate values ranging from $0^{\circ}$ to $30^{\circ}$ (average values ranging from $15^{\circ}$ to $20^{\circ}$ ) in joints without disk displacement, in post-mortem specimens (Westesson, Liedberg ${ }^{18}$, 1987; Westesson et al. ${ }^{19}, 1991$; Katzberg, Westesson $^{7}$, 1994).

In a correlation with the knee joint, whose investigation has reached a more mature state than that of the TMJ, Fu et al. ${ }^{4}$ (1994) affirmed that angular deformities may promote articular diseases, such as arthritis, and that the opposite is also true: deformities may happen as a consequence of the evolution of an articular degenerative disease.

Thus, the aim of the present research was to evaluate the relationship between HCA magnitude and ID as a result of TMJ disk interference in individuals who had been referred to MR scans.

\section{MATERIAL AND METHODS}

One hundred and forty-four MR file images of the TMJ area were appraised from November 2000 to July 2001, according to the parameters described in Table 1 . The subjects, 57 females and 15 males, had ages from 15 to 70 years.

As a rule, the clinical exam included directing the anamnesis of all the subjects to the main complaint and palpating TMJs when maximum opening of the mouth was achieved.

The MR scans were made in a Signa system model (General Electric, Milwaukee, WIS, USA), at a magnetic field magnitude of $1.5 \mathrm{~T}$, using a bilateral radiofrequency surface coil of $6.5 \times 6.5 \mathrm{~cm}$ in size.

For the acquisition of the final scan in T1, an axial scout was performed. Based on that, the condyle was located and a record of the horizontal angle (supplied by the system) was made. Hence,

TABLE 1 - Parameters for obtaining TMJ T1 images.

\begin{tabular}{l|c|c|c|c|c|c|c}
\hline \hline \multicolumn{1}{c|}{ Image } & $\begin{array}{c}\text { TR } \\
(\mathrm{msec})\end{array}$ & $\begin{array}{c}\text { TE } \\
(\mathrm{msec})\end{array}$ & NEX & $\begin{array}{c}\text { FOV } \\
(\mathrm{cm})\end{array}$ & $\begin{array}{c}\text { Slice thickness } \\
(\mathrm{mm})\end{array}$ & Matrix & Imaging time \\
\hline Axial localizer (closed jaw) & 400 & 13 & 1 & 24 & 4 & $256 \times 256$ & $58^{\prime \prime}$ \\
\hline Parassagital (closed jaw) & 400 & 13 & 4 & 14 & 2 & $256 \times 256$ & $5^{\prime} 12^{\prime \prime}$ \\
\hline Parassagital (open jaw) & 400 & 13 & 4 & 14 & 2 & $256 \times 256$ & $5^{\prime} 12^{\prime \prime}$ \\
\hline \hline
\end{tabular}

$\mathrm{NEX}=$ number of excitations; FOV = field of view; TR = time of repetition; $\mathrm{TE}=$ time of echo. 
Crusoé-Rebello IMR, Campos PSF, Rubira IRF, Panella J, Mendes CMC. Evaluation of the relation between the horizontal condylar angle and the internal derangement of the TMJ - a magnetic resonance imaging study. Pesqui Odontol Bras 2003;17(2):176-82.

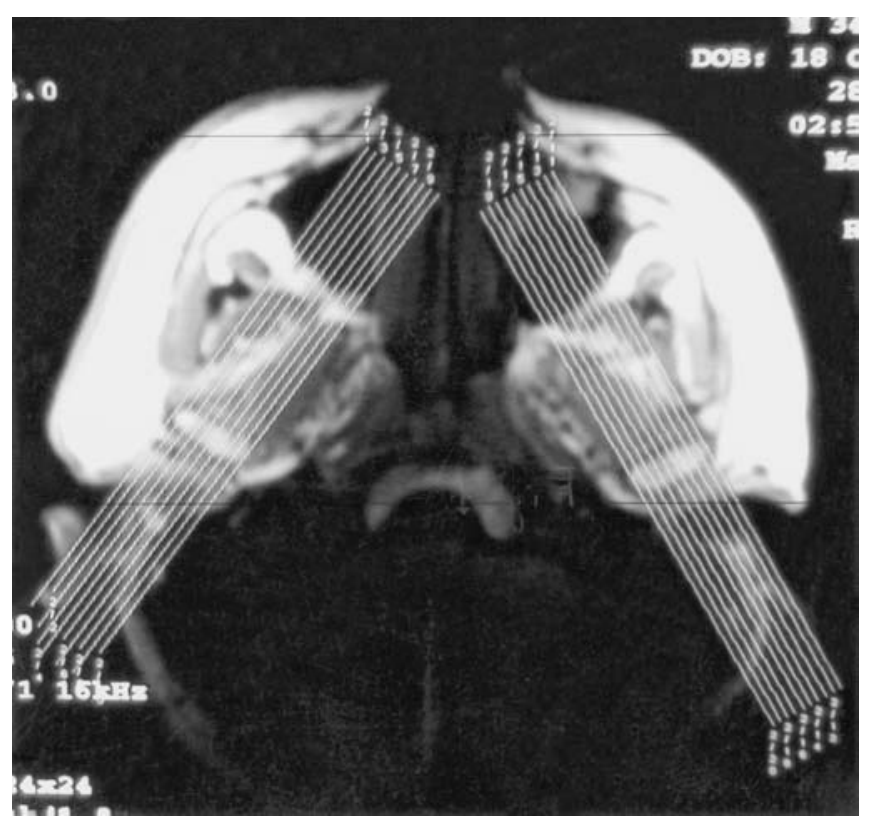

FIGURE 1 - Axial localizer exhibiting the orientation tool for the parassagittal cuts, which is also the one that allows automatic measurement of the horizonal condylar angle.

the sequence of perpendicular cuts along the condyle axis (Figure 1) was determined.

The scans were interpreted by an experienced examiner who used the same diagnosis criteria as proposed by Katzberg, Westesson ${ }^{7}$ (1994), and Milano et al. ${ }^{9}$ (2000). For the purpose of data analysis, only two groups were identified: normal TMJs and TMJs affected with articular disk displacement. Therefore, the aspect of reduction or non-reduction was not separately considered. The same applies to the different types of articular disk displacement, although the discussion that follows has considered all of the aspects involved.

Additionally, bone changes were interpreted as either adaptive or degenerative. To be considered adaptive, a change could be faceted, but show no cortical erosion or affection of the subchondral portion. The presence of the latter aspects was interpreted as an evidence of a degenerative change, especially if accompanied by subchondral sclerosis, osteophytes or subchondral cysts.

In order to perform a statistical analysis, descriptive parameters of the distribution of the variables of interest, measured to the minimum in an ordinal scale, were estimated. In addition, the Shapiro-Wilk test of adherence to normal distribution and the Spearman test $(\rho)$ of correlation of positions (to check the degree of compliance among
TABLE 2 - Descriptive statistics of all right horizonal condylar angle values obtained for the respective diagnosis groups in the sample.

\begin{tabular}{c|c|c|c|c|c|c}
\hline \hline \multirow{2}{*}{ Age } & \multicolumn{3}{|c|}{ Female } & \multicolumn{3}{c}{ Male } \\
\cline { 2 - 7 } & BD & UD & WD & BD & UD & WD \\
\hline $10-19$ & 1 & 4 & 2 & 2 & 1 & - \\
\hline $20-29$ & 3 & 7 & 3 & 1 & 2 & 1 \\
\hline $30-39$ & 7 & 5 & 7 & - & 1 & 2 \\
\hline $40-49$ & 5 & 1 & 2 & - & - & 2 \\
\hline $50-59$ & 3 & 1 & 3 & 1 & 2 & - \\
\hline $60-69$ & 1 & - & - & - & - & - \\
\hline $70-79$ & 2 & - & - & - & - & - \\
\hline \hline
\end{tabular}

BD - bilateral displacement; UD - unilateral displacement; WD - without displacement.

techniques), as well as the $t$-Student and the Pearson chi-square tests, were made.

\section{RESULTS}

Of the 144 appraised joints, 68 fell within normality and 46 showed an anterior disk displacement with reduction. Of these, 41 featured some type of condylar adaptive change, whereas 5 presented degenerative changes. Twenty-nine joints showed an anterior disk displacement without reduction, of which 12 featured condylar adaptive changes and 17, degenerative changes. In one case, a posterior disk displacement was observed.

The type of displacement showed no predominance as regards gender and age groups (Table 2).

The distribution of the HCA values followed a similar behavior both for the male and female groups (Graph 1).

On the other hand, it was not possible to establish a correlation between left and right HCA values and the subjects' age (Graph 2).

The average HCA values for joints whose disks were in a normal position were $22.09^{\circ}$ (RAV) and $21.47^{\circ}$ (LAV). For joints presenting disk displacement, such values were $24.69^{\circ}$ (RAV) and $22.94^{\circ}$ (LAV) (Table 3 and 4).

The group with a disk displacement diagnosis presented larger average values than the group with a normal diagnosis. In addition, their HCA values fell within a higher range (Graph 3).

A statistically significant association was observed between HCA values (57.8\%), normal position diagnoses (69.7\%) and articular disk displacement diagnoses $(66.7 \%)$, for contralateral TMJs. 
Crusoé-Rebello IMR, Campos PSF, Rubira IRF, Panella J, Mendes CMC. Evaluation of the relation between the horizontal condylar angle and the internal derangement of the TMJ - a magnetic resonance imaging study. Pesqui Odontol Bras 2003;17(2):176-82.

TABLE 3 - Descriptive statistics of all right horizonal condylar angle values obtained for the respective diagnosis groups in the sample.

\begin{tabular}{c|c|c|c|c|c|c|c|c}
\hline \hline Diagnosis & $\mathrm{n}$ & Mean & Standard deviation & Min & $25 \%$ & $50 \%$ & $75 \%$ & Max \\
\hline Normal & 33 & 22.09 & 3.95 & 14 & 20 & 22 & 24 & 31 \\
\hline Displacement & 39 & 24.69 & 6.41 & 15 & 20 & 23 & 29 & 41 \\
\hline \hline
\end{tabular}

TABLE 4 - Descriptive statistics of all left horizonal condylar angle values obtained for the respective diagnosis groups in the sample.

\begin{tabular}{c|c|c|c|c|c|c|c|c}
\hline \hline Diagnosis & $\mathrm{n}$ & Mean & Standard deviation & Min & $25 \%$ & $50 \%$ & $75 \%$ & Max \\
\hline Normal & 36 & 21.47 & 4.81 & 9 & 18.5 & 22 & 24 & 31 \\
\hline Displacement & 36 & 22.94 & 6.59 & 10 & 18.5 & 24 & 27 & 39 \\
\hline \hline
\end{tabular}

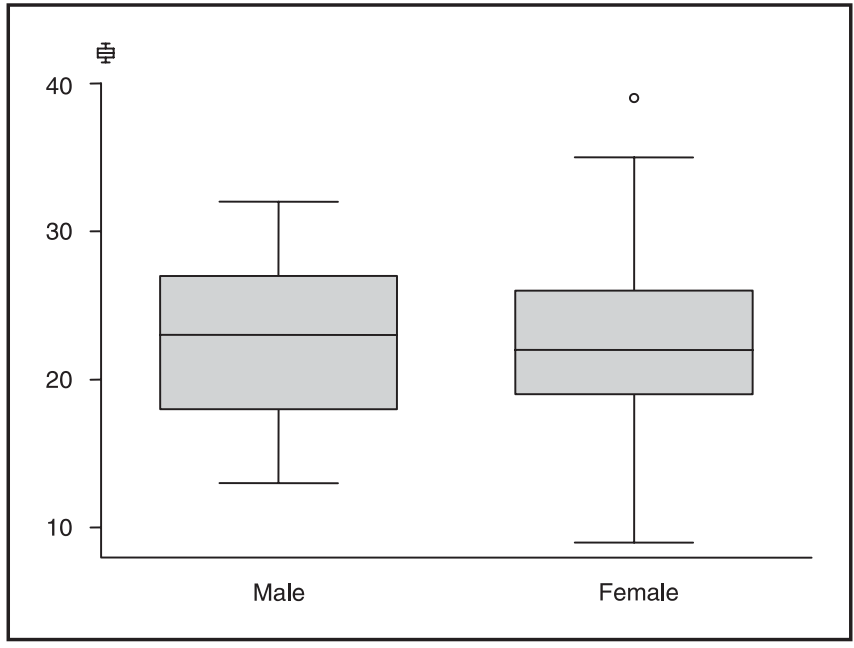

GRAPH 1 - Distribution of horizonal condylar angle values among male and female groups.

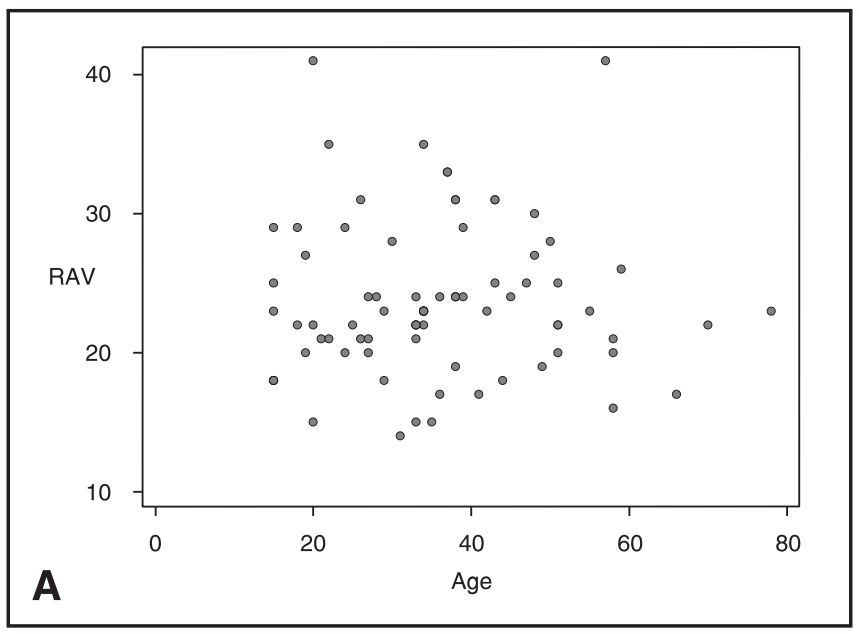

GRAPH 2 - Distribution of right (RAV) (A) and left (LAV)
When contralateral horizonal condylar angles were compared, a correlation of $63.31 \%$ was obtained. Concerning the diagnosis of the articular condition, a correlation of $68.05 \%$ was verified.

\section{DISCUSSION}

Since MR is an imaging diagnostic method of recent and still limited use in stomatology, all knowledge resulting from its application will contribute to more precise indications. In the field of research on MR, the work of Campos ${ }^{1}$ (2001) stands out for the vast number of cases considered (512 individuals) in the evaluation of cystic sinuses scans.

Starting from a sample of 56 children and young adults, Ribeiro's ${ }^{14}$ (1996) pioneering work on TMJ gathered substantial information regarding the TMJ in asymptomatic patients in the city of

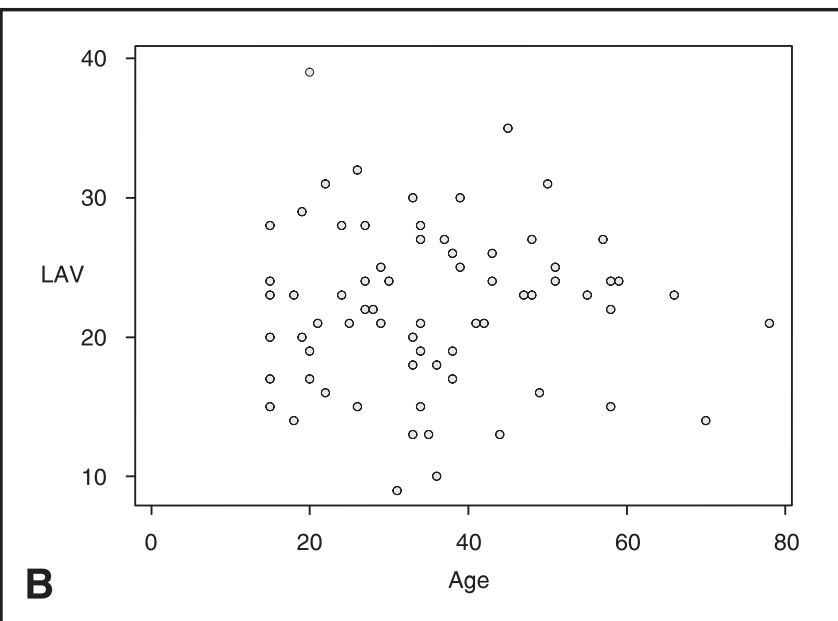

(B) horizonal condylar angle values according to age. 
Crusoé-Rebello IMR, Campos PSF, Rubira IRF, Panella J, Mendes CMC. Evaluation of the relation between the horizontal condylar angle and the internal derangement of the TMJ - a magnetic resonance imaging study. Pesqui Odontol Bras 2003;17(2):176-82.

São Paulo. And to mention another Brazilian researcher, Tanaka ${ }^{17}$ (2000) analyzed the effect of stabilizing devices in the treatment of 40 patients suffering from TMD using MR scans.

Therefore, our work aimed at offering a contribution to the consolidation of the knowledge concerning TMJ, its morbid conditions and the application of MR in dentistry.

As regards the circumstances in which TMD occurs, the absence of an articular disk displacement in symptomatic individuals is a finding as common as the reverse. In observing the normal relationship between condyles and disks, Westesson et al. ${ }^{19}$ (1991) have not found any statistically significant differences between the groups of symptomatic and asymptomatic patients.

Cholitgul et al. ${ }^{2}$ (1997) have observed that pain had not been a symptom characteristic to the several types of disk displacement when an association was sought between the symptoms reported by the patients and the findings brought about by MR scans. Therefore, the relationship between ID and painful symptoms remains unclear. Isberg et $a .^{6}(1998)$, on the other hand, have not reported an increase in pain among women when evaluating patients suffering from ID.

According to Okeson ${ }^{11}$ (1996), female individuals are more predisposed to disorders resulting from the interference of the articular disk. Nevertheless, we have observed here that both males and females share the same characteristics as regards ID and horizonal condylar angle values (Table 2). We could say, at first, that hormonal factors do not seem to play a significant role in the manifestation of IDs in TMJs.

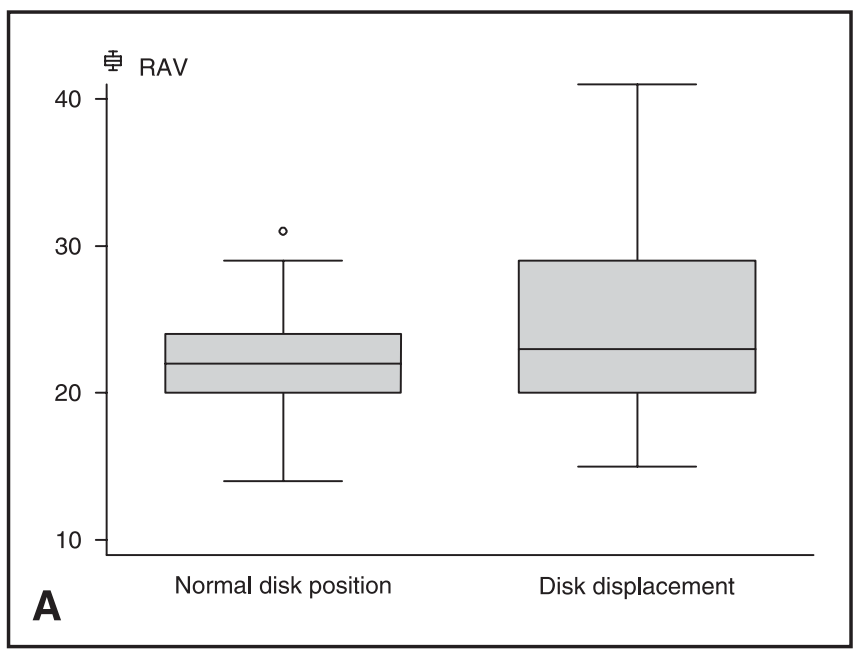

GRAPH 3 - Distribution of right (RAV) (A) and left (LAV) (B) horizonal condylar angle values for normal disk position and disk displacement TMJs.

In this study, we could not find an association between the increase in age and the increase in horizonal condylar angle (Graph 2) values. And we have not detected any associations between ID and age either. Although they have obtained similar results to the ones we share here, Isberg et al. ${ }^{6}$ (1998) have excepted a tendency towards an increase in the incidence of symptomatic disk displacements during the second decade of life, there being a peak in the incidence of asymptomatic displacements during puberty, for both genders. Our sample, on the contrary, has evidenced a greater concentration of individuals in their thirties and forties.

The results we obtained demonstrated that average horizonal condylar angle values, so much to the right side as to the left side, were higher in individuals with positive diagnoses for ID (Table 3 and 4, Graph 3). Although our findings do not show a statistically significant difference between the average horizonal condylar angle values of normal TMJs and TMJs with ID, our data reveal a tendency among TMJs with ID to present higher horizonal condylar angle values. According to Katzberg, Westesson ${ }^{7}$ (1994), joints with higher horizonal condylar angle values would either tend to develop ID and articular degenerative diseases or they would be the result of a remodeling process.

Some studies have considered the remodeling hypothesis more plausible. Westesson et al. ${ }^{19}$ (1991), however, speculate that joints with higher horizonal condylar angle values have a higher possibility of stretching the lateral ligament between the disk and the condyle during the movement of

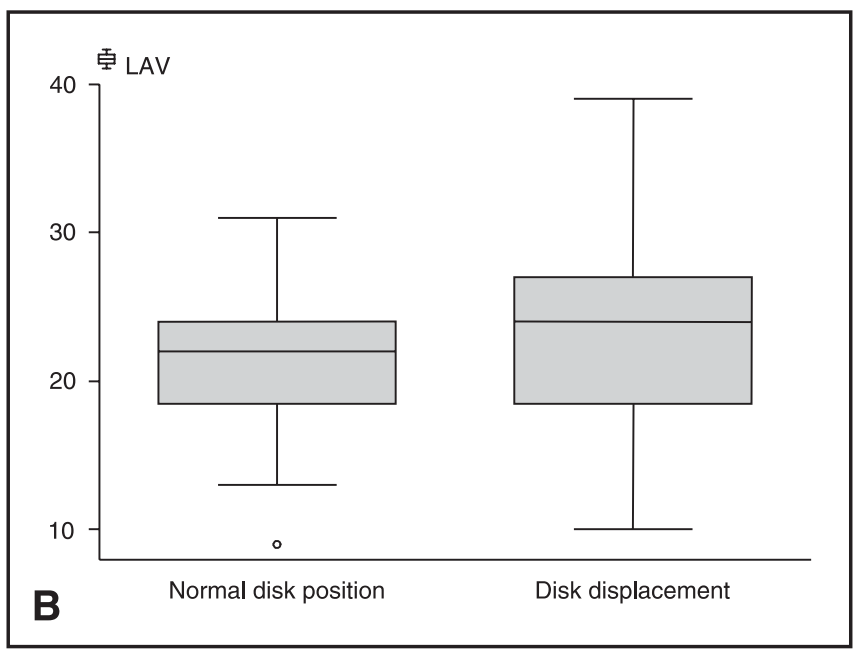


Crusoé-Rebello IMR, Campos PSF, Rubira IRF, Panella J, Mendes CMC. Evaluation of the relation between the horizontal condylar angle and the internal derangement of the TMJ - a magnetic resonance imaging study. Pesqui Odontol Bras 2003;17(2):176-82.

translation, as compared to TMJs with lower horizonal condylar angle values. Since the lateral ligament is not as stretchable as the disk's posterior ligament, a distension beyond the limits could result in permanent stretching, with a subsequent displacement of the articular disk. Our results, on the other hand, do not allow for the inference that an increase in the horizonal condylar angle is either the cause or the consequence of ID. However, from an embryogenic point of view, the development of the articular components in the absence of factors that could determine structural changes occurs in a harmonious way. In other words, the spatial orientation of the condyle will always comply with the spatial orientation of the articular fossa, which leads to a normal functional condition, in spite of anatomical variations. For that reason, we believe ID to be the cause, and not the consequence, of increased horizonal condylar angle values.

Finally, the comparison between the horizonal condylar angle values, as well as between the conditions of the joint (normal or with disk displacement), has showed that each joint behaves in a similar way to the contralateral joint (Graph 3). This suggests that one joint influences the other and, for that reason, they cannot be considered separately, as in the study by Nebbe et al. ${ }^{10}$ (1998). The mandible movements are coordinated by both joints, which are functionally unified. And functional unification could justify the high prevalence of

\section{REFERENCES}

1. Campos PSF. Estudo tridimensional de imagens císticas dos seios maxilares, através da ressonância magnética nuclear, numa amostra populacional da cidade do Salvador [Tese de Doutorado]. São Paulo: Faculdade de Odontologia da USP; 2001.

2. Cholitgul W, Nishiyama H, Sasai T, Uchiyama Y, Fuchihata $\mathrm{H}$, Rohlin M. Clinical and magnetic resonance imaging findings in temporomandibular joint disc displacement. Dentomaxillofac Radiol 1997;26:183-8.

3. Dolwick MF, Katzberg RW, Helms CA. Internal derangements of the temporomandibular joint: fact or fiction? J Prosthet Dent 1983;49:415-8

4. Fu FH, Harner CD, Vince KG. Biomechanical factors in alignment and arthritic disorders of the knee. Knee Surgery. v. 2. Baltimore: Williams \& Wilkins;1994.

5. Heffez LB, Mafee MF, Rosenberg H. Imaging atlas of the temporomandibular joint. Baltimore: Williams \& Wilkins; 1995.

6. Isberg A, Hägglung M, Paesani D. The effect of age and gender on the onset of symptomatic temporomandibular joint disk displacement. Oral Surg Oral Med Oral Pathol Oral Radiol Endod 1998;85:252-7. bilateral alterations, as observed by Katzberg ${ }^{8}$ (1989).

\section{CONCLUSIONS}

While the average horizonal condylar angle values in individuals without ID were $22.09^{\circ}$ and $21.47^{\circ}$, on the right and left sides, respectively, for ID patients such values were $24.69^{\circ}$ and $22.94^{\circ}$, and this demonstrates a tendency towards higher horizonal condylar angle values in TMJs with ID.

For contralateral TMJs, we have observed a close association between the horizonal condylar angle values $(57.8 \%)$, normality conditions $(69.7 \%)$, and ID (66.7\%). And, corroborating those results, we have found a correlation between the contralateral horizonal condylar angle values $(63.31 \%)$ and the diagnosis of contralateral TMJs (68.05\%). For that reason, we could infer that there is a tendency for contralateral TMJs to share the same characteristics and conditions, since they work as a functional unit.

\section{ACKNOWLEDGEMENTS}

This study was supported by Grants from the Fundação Coordenação de Aperfeiçoamento de Pessoal de Nivel Superior (CAPES), Brazil. We sincerely appreciate the trust and collaboration offered by Dr. Delfin and Dr. Maria Olivia Gonzalez, who have made this research possible.

7. Katzberg RW, Westesson P-L. Diagnosis of the Temporomandibular joint. Philadelphia: W. B. Saunders Co.; 1993.

8. Katzberg RW. Temporomandibular joint imaging. Radiology 1989;170:297-307.

9. Milano V, Desiate A, Bellino R, Garofalo T. Magnetic resonance imaging of temporomandibular disorders: classification, prevalence and interpretation of disc displacement and deformation. Dentomaxillofac Radiol 2000;29:352-61.

10. Nebbe B, Major PW, Prasad NG, Hatcher, D. Quantitative assessment of temporomandibular joint disk status. Oral Surg Oral Med Oral Pathol Oral Radiol Endod 1998; 85:598-607.

11. Okeson J. Oral facial pain - guidelines for assessment, diagnosis and management. Chicago: Quintessence, 1996.

12. Paesani D, Westesson PL, Hatala M, Tallents RH, Kurita K. Prevalence of temporomandibular internal derangements in patient with craniomandibular disorders. Am J Orthod Dentofacial Orthop 1992;101:41-7.

13. Pullinger AG, Solberg WK, Hollender L, Guichet D. Tomographic analysis of mandibular condyle position in diagnostic subgroups of temporomandibular disorders. J Prosthet Dent 1986;55:723-35. 
Crusoé-Rebello IMR, Campos PSF, Rubira IRF, Panella J, Mendes CMC. Evaluation of the relation between the horizontal condylar angle and the internal derangement of the TMJ - a magnetic resonance imaging study. Pesqui Odontol Bras 2003;17(2):176-82.

14. Ribeiro RF. Avaliação estrutural da articulação temporomandibular em crianças e adultos jovens assintomáticos através de imagens por ressonância magnética [Tese de Doutorado]. Bauru: Faculdade de Odontologia da USP; 1996.

15. Sano T. Recent developments in understanding temporomandibular joint disorders. Part 1: bone marrow abnormalities of the mandibular condyle. Dentomaxillofac Radiol 2000; 29:7-10.

16. Tallents RH, Katzberg RW, Murphy W, Proskin H. Magnetic resonance imaging findings in asymptomatic volunteers and symptomatic patients with temporomandibular disorders. J Prosthet Dent 1996; 75:529-33.
17. Tanaka EE. Análise dos efeitos da terapia com placas estabilizadoras em pacientes com disfunção têmporomandibulares por meio de ressonância magnética [Tese de Doutorado]. São Paulo: Faculdade de Odontologia da USP; 2000.

18. Westesson PL, Liedberg J. Horizontal condylar angle in relation to internal derangement of the temporomandibular joint. Oral Surg Oral Med Oral Pathol 1987; 64:391-4.

19. Westesson PL, Bifano JA, Tallents RH, Hatala MP. Increased horizontal angle of the mandibular condyle in abnormal temporomandibular joints. A magnetic resonance imaging study. Oral Surg Oral Med Oral Pathol 1991; 72:359-63

Recebido para publicação em 15/03/02

Enviado para reformulação em 30/01/03

Aceito para publicação em 07/05/03 